\title{
Use of the Geometrical Instruments in the Teaching and Learning of Geometry in Secondary Schools: A Case Study of Masaiti District, Zambia
}

\author{
Siwale Philip ${ }^{*} \quad$ Hamanenga Jacob \\ The Copperbelt University, School of Mathematics and Natural Sciences.
}

\begin{abstract}
The purpose of the study was to establish the challenges that are faced by learners when using geometrical instruments in Masaiti district and how these affect their performance in geometry. The study was based on four objectives; to assess the level of availability of the instruments for teachers and pupils, to establish the extent to which the instruments are used and the challenges that are faced by learners when using these instruments, and how use of these instruments affect learner's performance. 256 grade 11 pupils were proportionately and simple randomly selected to complete the learners' questionnaires. 80 pupils for both a typical and an ideal class were purposively selected for observable activities. The study adopted a descriptive survey design. Findings showed that the geometrical instruments were insufficient in these schools and therefore scarcely used. The following challenges were found; sharing instruments, inaccurate measurements, lack of interest and pre-requisite knowledge, use of free hand, difficulty geometry language, time consuming, and bad attitude by some teachers, use of inappropriate instruments and defective instruments, stiff finger muscles, shaking and poor sight. The hypothesis was tested with the independent t-test on Excel software. The results showed that learners who used sufficient instruments performed better than those who shared. This was because the $\mathrm{p}(\mathrm{T}<=\mathrm{t})$ two-tail=1.58 was less than the critical t-value of 2.02 , at 0.95 level of significance. It was concluded that practice with instruments can improve performance in geometry.
\end{abstract}

Keywords: geometry, geometrical instruments, use, availability, challenges, teaching, learning

DOI: $10.7176 /$ JNSR/9-16-07

Publication date: August $31^{\text {st }} 2019$

\subsection{INTRODUCTION}

Geometry is a branch of mathematics which deals with the study of shapes or figures and their properties (Paulina, 2007). In the Zambian Secondary school syllabus, some examples of topics under geometry include; Geometric construction, shapes and polygons, mensuration, and transformation geometry. Teaching and learning of these geometrical topics require effective use of geometrical instruments if geometry is to provide a rich source of visualization for understanding arithmetical, algebraic, and statistical concepts (Battista, 1999). Research study by Massey, Ndiyo, and Joshua (2010) on the influence of instructional materials showed that non-availability of geometrical instruments was one cause for poor performance in mathematics in Nigeria. They discovered that students who used these tools performed well in mathematics while those who failed to use the tools, despite being availed to them, performed poorly.

Ideally, the basic tools that are required for the teaching and learning of geometry are; pair of compasses, ruler (straightedge), protractor, set squares, and a pencil. The technique of measuring and constructing is essential and crucial in the teaching and learning of geometry. In several schools of Zambia, both rural and urban districts, teachers in the past brought to class a carton box or a bag containing mathematical sets to give to every pupil. Why was this important? Nowadays this is not the case anymore. No doubt, in well-developed nations, schools have other experiences with the advent of computers.

According to the Zambian syllabus for senior mathematics (2013), the main rationale tor teaching mathematics is focused on one principal goal; the subject fosters the development and improvement of learners' intellectual competence in logical reasoning, spatial visualization, analysis, and abstract thought. It is widely believed that constant practice can result in perfection. Psychomotor development relies on this principle. Of course, the above rationale is heavily dependent on hands on activities, and use of geometrical instrument is one principal aspect.

The researcher, therefore, saw the need to investigate and obtain data on this vital subject matter concerning availability and utilization of geometrical instruments in Masaiti district. Availability, adequacy, selection, and use of instructional materials are related to critical issues in teacher professional practice (Okon, 2005). Teachers and their students cannot use the tools that are not available. Unless the right tools are available and used correctly, good performance by pupils may not be achieved.

\subsection{PROBLEM STATEMENT}

The Examinations Council of Zambia (ECZ) Chief Examiners' reports for both the Junior Secondary School 
Leaving Examinations (JSSLE) and School Certificate Examinations (SCE), for the years 2014, 2015, 2016, and 2017, identified geometry as one of the study areas in mathematics in which candidates have not been performing satisfactorily. Each year, most students in Masaiti district are seen to avoid questions that require the use of geometrical instruments both in mock and school certificate examinations. Questions on geometric construction are usually attempted although with minimal accuracy, exactness, and precision. At grade 12, questions on transformation geometry are rarely favored. Dismal performance in geometry certainly has contributed to falling pass rates in mathematics in the district every other year. This is because geometry account for over $65 \%$ composition in national examinations at both levels.

Scholars worldwide have pointed to a number of factors as causes for the consistently poor pupils' performance in geometry, for example; language issues, readiness and so forth. Eniayeju (1987) and Okon (2005) point to the use and availability of geometrical instruments, as one major cause of this problem. Therefore, the researcher sought to carry out a research on this topic in secondary schools in Masaiti district based on the following objectives:

\subsection{RESEARCH OBJECTIVES}

The general objective of this study was to establish the challenges that are faced by learners when answering questions that require the use of geometrical instruments in secondary schools in Masaiti district and how these affect their performance in geometry.

\subsubsection{Specific Objectives}

1. To assess the level of availability of the geometrical instruments for teachers and pupils in secondary schools in Masaiti district

2. To establish the extent to which the geometrical instruments are used by teachers and pupils during geometry lessons in Masaiti district.

3. To establish the challenges that are faced by learners when answering questions that require the use of geometrical instruments in Masaiti district.

4. To establish the extent to which geometrical instruments affect learner's performance between learners who learn with sufficient geometrical instruments and those who learn with insufficient geometrical instruments.

\subsection{SIGNIFICANCE OF THE STUDY}

The results of this study will be useful to a number of persons. Learners will begin to like questions that require use of geometrical instruments and hence improve general performance in mathematics. Teachers of mathematics will be helped in evaluating their teaching strategies of geometry and recognising strengths and weaknesses in their current practices. The study will provide an exemplary model for District Education Standard Officers (DESO), Head teachers, and Heads of Departments (HODs) of Mathematics, for such instructional materials support, monitoring, and evaluation. Findings will help Teacher trainers (Colleges and Universities) to upscale in equipping the teacher trainees with appropriate skills useful in the use of geometrical instruments. Results of this study will be of paramount importance not only to the Zambian people but even beyond. The shoddy works we see, especially of late, in house constructions, road constructions and other Architectural designs suggests lack of enough exposure to the use of geometrical instruments by some workforce personnel during their schooling days.

\subsection{CONCEPTUAL FRAMEWORK}

This study is based on a conceptual framework that depicts improved performance in geometry as dependent variable, and availability and use of geometrical instruments as independent variables. It shows how the use of pair of compasses, straightedge (ruler), protractor, and set squares can improve learner's performance in geometry in particular and mathematics in general. Below is figure 1.10.1 showing the relationship between the independent variables (use) and the dependent variable (performance). 
Independent Variables

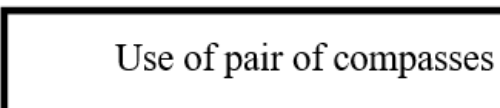

Use of straightedge (ruler)

Use of protractor

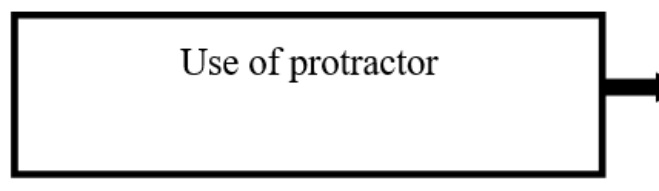

Use of set square

Figure.1.5.1: Conceptual framework.
Intervening Variables

Dependent Variable

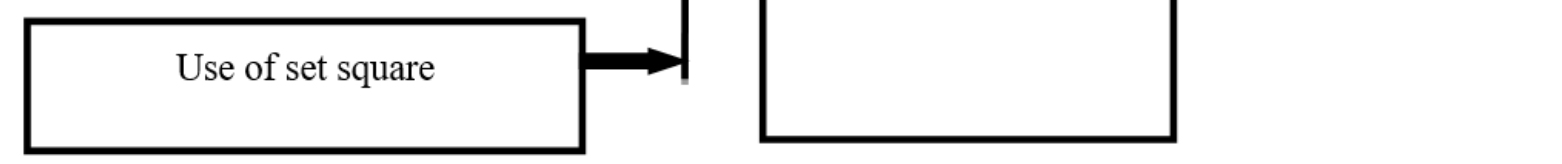

\subsection{LITERATURE}

In this study, geometrical instruments refers to basic tools that are required for the teaching and learning of geometry which are; pair of compasses, ruler (straightedge), protractor, set squares, and pencil used by teachers and learners.

\subsection{AVAILABILITY OF GEOMETRICAL INSTRUMENTS}

Research carried out in Nigeria on the availability of geometrical instruments has shown that these tools were not adequate in schools. In rural areas especially, most pupils were found learning mathematics without mathematical sets. Chalkboard instruments were also found to be in shortfalls as compared to the number of teachers.

From the world's view, these geometrical instruments are becoming less useful in well developed countries where geometry software is used. A study which was conducted by Bassey et al (2010) on the influence of instructional materials on mathematics achievement in Cross River State, Nigeria, reviewed that availability of instructional materials was grossly inadequate in all the schools. Teachers rated materials availability at $29.5 \%$. In the same country, Fabiyi (2017) conducted a research in Ekiti State on Geometry Concepts in Mathematics Perceived Difficult to Learn. He established that non- availability of geometrical instruments was among other causes. In both cases, the researchers found that most pupils could not afford a mathematical instrument set due to lack of funds. Schools could also not buy enough chalkboard instruments due to poor funding by their government.

Similarly, a research done by Tety (2016) in Tanzania about the role of instructional materials (geometrical instruments inclusive) showed that non-availability of these tools was one of the contributing factors to poor academic performance in Rombo district. These findings imply that instruments that are not available both to the teachers and learners could not be used.

A research carried in New Jersey, United States of America by Geddes and Fortunato on Geometry and Spatial Sense pointed out that all students could develop spatial sense and an ability to use geometric properties and relationships to solve problems in mathematics and everyday life. Further they contended that; wellconstructed diagrams allow us to apply knowledge of geometry, geometric reasoning, and intuition to arithmetic and algebra problems (Geddes et al, 1993). They cited examples like the use of a rectangular array of geometry to model the multiplication of two quantities as a long known effective strategy to aid in the visualization of the operation of multiplication.

\subsection{USE OF GEOMETRICAL INSTRUMENTS}

Findings by Bassey et al (2010) in Ekiti State showed that both chalkboard instruments and mathematical set instruments were not used. Only the meter rule, chalkboard, and duster were rated used. They discovered that 
instructional materials were hardly used in daily instruction. Thus the aggregate usability in these secondary schools was $34.72 \%$.

In 2016, Chikwere and Ayama conducted a research on Teaching of Geometric Construction in Junior High School in Ghana. The interventional study sought to find the difference in the performance of pupils who were taught geometric construction using abstract methods (AM) and those who were taught using practical methods (PM). They noticed also that the inability of pupils in the (AM) group to construct figures was attributed to lack of appropriate teaching and learning materials (TLMs) and poor teaching methods.

Their findings were supported by Sarfo, Eshun, Elen and Adentwi (2014) that the use of physical facilities such as models would help grasp the idea of geometry which seems to be abstract. It is the facilities in terms of infrastructure, equipment and materials that afford the students the opportunity to acquire the necessary knowledge (Sarfo et al., 2014). They were also supported by Adolphus (2011) who suggested among other factors that inadequate provision of teaching and learning materials and facilities do not motivate teaching and learning of geometric construction.

As much as the researcher agrees with Chikwere and Ayama's work, he feels the results of their findings were obvious. It was expected that pupils who were taught using practical methods (PM) with all the teaching and learning materials (TLMs) provided to them were given advantage to perform better than the pupils who were taught using abstract methods (AM) with limited instructional materials. Instead they could have explored the issues surrounding pupil's attitudes, behaviors, and competences during geometric construction lessons. These could have been evaluated in order to bring about uniform change in performance to all the sampled pupils.

\subsubsection{CHALLENGES FACED BY LEARNERS WHEN ANSWERING QUESTIONS THAT REQUIRE USE OF GEOMETRICAL INSTRUMENTS.}

2015 Examinations Performance Review Report by the examinations Council of Zambia (ECZ), reviewed some challenges experienced by candidates at Grade 9 in answering questions on geometric construction and drawing of a pie chart under statistics. ECZ reported that most of the challenges faced by candidates were as a result of lack of mastery of the concepts and skills taught at this level which was evidenced by the use of free hand in answering a question on Geometrical construction. The challenges were attributed to the teachers not having taught the topic well or lack of teaching and learning materials like mathematical instruments for use by both the teachers and the learners.

The study by Madanzi (2015), sought to identify the challenges faced by learners in learning geometrical construction and locus at Cheziya Gokwe High School in Zimbabwe. His findings provided evidence that; lack of infrastructure, large class size, lack of mathematical sets, and the use of exercise books with lines were found to be the major factors which were responsible for the difficulty in the teaching and learning of geometrical construction and locus.

\subsubsection{THE EXTENT TO WHICH GEOMETRICAL INSTRUMENTS AFFECT LEARNER'S PERFORMANCE}

In his research work, Adeogun (2001) revealed that there was a strong positive link between instructional resources and academic performance. According to Adeogun, schools that possessed adequate instructional resources performed better than schools that hard few instructional resources. His findings concurred with the study by Babayomi (1999) that private schools performed better than public schools because of the availability and adequacy of teaching and learning resources.

Fuller and Clark (1994) suggested that the quality of instructional processes experienced by a learner determines quality of education. In their view they suggest that quality instructional materials create into the learner's quality learning experience. Mwiria (1995) also indicated that student's performance was affected by the quality and quantity of teaching and learning resources.

\section{RESEARCH METHODOLOGY 3.0 RESEARCH DESIGN}

The research design that was employed in this study was a descriptive survey, especially chosen because the research was non-experimental, as it was carried out in an uncontrolled environment.

\subsection{STUDY POPULATION}

The study population comprised; 5 Head teachers, 28 teachers of mathematics in the five secondary schools that were purposively selected, 256 grade 11 pupils were selected using a simple random method and were meant to complete the learner's questionnaire, and 80 pupils were purposively selected to carry out activities in the typical and ideal classes. 


\subsection{RESEARCH INSTRUMENTS}

In this study, four types of measuring instruments were used. The teacher geometrical instruments availability questionnaire (TGIAQ) and the learner geometrical instruments use questionnaire (LGIUQ), Observation schedule (OS), two standardized performance tests for 80 purposively selected pupils were administered before and after a series of practical work, and Head teacher's interview guide. TGIAQ was meant for 28 teachers of mathematics that were purposively selected, while LGIUQ was meant for 256 pupils that were randomly selected. This approach was considered appropriate because pupils could honestly assess the use of these tools, while teachers were in a better position to report on availability of the same instruments. Five Head teachers from 5 purposively selected schools also provided data on availability and use of geometrical instrument through an Interview Guide which they completed. The researcher made an all-round observations including availability and use of geometrical instruments and the challenges faced by learners when answering questions that required the use of geometrical instruments.

\subsection{VALIDITY OF INSTRUMENTS}

The research instruments were piloted at Chamunda Secondary School (newly upgraded) which was not part of the selected schools for the study. The questionnaires for pupils were completed by all the forty-two (42) grade 11 pupils at this school. The pupils also attempted to answer all the pre-test items. This exercise enabled the researcher to make vital adjustments to the question items and the learners' questionnaire. Pilot was done to establish the construct validity of the instruments (Mugenda \& Mugenda, 2003). My supervisor did the face validity of all the measuring instruments.

\subsection{DATA COLLECTION PROCEDURES}

The study involved the use of two types of questionnaires for teachers and for pupils. The questionnaires contained both closed and open ended questions. One subject teacher for grade 11s was allowed to teach the selected learners by using the planned activities. These lessons required the use of geometrical instruments. Due to many activities that were going on in the site school, the researcher was only given 7 days to do this exercise. Two days were used to administer a pre-test and a post- test, while five days were used for teaching and learning. During this period the researcher made observations and took photographs. Post-test was given to measure positive change as this was an interventional study. Participating Head teachers also submitted data through the interview guide which they completed.

\subsection{DATA ANALYSIS TECHNIQUES}

Data analysis techniques are statistical methods used to analyse data so that it can be interpreted (Kombo \& Tromp, 2011). Data was analysed qualitatively through reports from teachers, learners, researcher's observations and Head teacher's interview guide responses and quantitatively through the use of Excel software and the Statistical Package for Social Sciences (SPSS Inc., software version 23.0)

The response options for availability were coded as follows:

Highly available $(\mathrm{HA})=4$, Available $(\mathrm{A})=3$, Scarcely available $(\mathrm{SA})=2$, Completely unavailable $(\mathrm{CU})=1$

The response options for the utilization were coded in a similar way as follows:

Highly used $(\mathrm{HU})=4$, Used $(\mathrm{U})=3$, Scarcely used $(\mathrm{SU})=2$, Completely not used $(\mathrm{CN})$

$$
=1
$$

This technique represented an item mean of 2.50. Any response mean for a particular item that was found below the item mean (2.50) was considered virtually unavailable and not used. Basing on the above criterion, response mean for each item was found and compared with the item mean to analyse objectives (1) and (2). In the case of objective (3) observation reports were used while question (4) both descriptive and inferential statistics were used.

\subsection{RESULTS AND DISCUSSIONS \\ 4.1 LEVEL OF AVAILABILITY OF GEOMETRICAL INSTRUMENTS. \\ 4.1.1 Views of teachers}

Results of the teachers' rating scores of availability of these instruments per item are presented in Table 4.1.1.1 below. The total score for each cell was found by multiplying the weight (option response) by the category frequency. The option responses were coded as indicated in section 3.6. The cell scores per item were added and then divided by 28 (sample of teachers) to obtain the item mean which was then compared to the scale mean 2.50 . 
Table 4.1.1.1: Teachers' rating of level of Availability of Geometrical Instruments in Secondary Schools.

\begin{tabular}{|c|c|c|c|c|c|c|}
\hline $\begin{array}{l}\text { Geometrical } \\
\text { Instrument }\end{array}$ & $\begin{array}{c}\text { Highly } \\
\text { Available } \\
\text { (4) }\end{array}$ & $\begin{array}{c}\text { Scarcely } \\
\text { Available } \\
\text { (2) }\end{array}$ & $\begin{array}{c}\text { Available } \\
\text { (3) }\end{array}$ & $\begin{array}{c}\text { Completely } \\
\text { Unavailable } \\
\text { (1) }\end{array}$ & $\begin{array}{l}\text { Item } \\
\text { Mean }\end{array}$ & Comment \\
\hline $\begin{array}{l}\text { Chalk board } \\
\text { Compasses }\end{array}$ & $\begin{array}{l}(2) \\
8\end{array}$ & $\begin{array}{c}(12) \\
24\end{array}$ & $\begin{array}{l}(14) \\
42\end{array}$ & $\begin{array}{c}(0) \\
0\end{array}$ & 2.6 & Available \\
\hline $\begin{array}{l}\text { Chalk board } \\
\text { Protractor }\end{array}$ & $\begin{array}{c}(1) \\
4\end{array}$ & $\begin{array}{c}(17) \\
34\end{array}$ & $\begin{array}{c}(10) \\
30\end{array}$ & $\begin{array}{c}(0) \\
0\end{array}$ & 2.4 & Not available \\
\hline $\begin{array}{l}\text { Chalk board } \\
\text { Ruler }\end{array}$ & $\begin{array}{c}(1) \\
4\end{array}$ & $\begin{array}{l}(7) \\
14\end{array}$ & $\begin{array}{c}(20) \\
60\end{array}$ & $\begin{array}{c}(0) \\
0\end{array}$ & 2.9 & Available \\
\hline $\begin{array}{l}\text { Chalk board } \\
\text { Set Square }\end{array}$ & $\begin{array}{c}(0) \\
0\end{array}$ & $\begin{array}{l}(19) \\
38\end{array}$ & $\begin{array}{l}(5) \\
15\end{array}$ & $\begin{array}{l}(4) \\
4\end{array}$ & 2.0 & Not available \\
\hline Duster & $\begin{array}{l}(9) \\
36\end{array}$ & $\begin{array}{c}\text { (3) } \\
6\end{array}$ & $\begin{array}{c}(16) \\
48\end{array}$ & $\begin{array}{c}(0) \\
0\end{array}$ & 3.2 & Available \\
\hline $\begin{array}{l}\text { Pupil's } \\
\text { Compasses }\end{array}$ & $\begin{array}{c}(0) \\
0\end{array}$ & $\begin{array}{c}(22) \\
44\end{array}$ & $\begin{array}{l}(4) \\
12\end{array}$ & $\begin{array}{c}(2) \\
2\end{array}$ & 2.1 & Not available \\
\hline $\begin{array}{l}\text { Pupil's } \\
\text { Protractor }\end{array}$ & $\begin{array}{c}(0) \\
0\end{array}$ & $\begin{array}{c}(22) \\
44\end{array}$ & $\begin{array}{l}(4) \\
12\end{array}$ & $\begin{array}{c}(2) \\
2\end{array}$ & 2.1 & Not available \\
\hline $\begin{array}{l}\text { Pupil's } \\
\text { Ruler }\end{array}$ & $\begin{array}{l}(2) \\
8\end{array}$ & $\begin{array}{c}(13) \\
26\end{array}$ & $\begin{array}{c}(13) \\
39\end{array}$ & $\begin{array}{c}(0) \\
0\end{array}$ & 2.6 & Available \\
\hline $\begin{array}{l}\text { Pupil's } \\
\text { Set Square }\end{array}$ & $\begin{array}{c}(0) \\
0\end{array}$ & $\begin{array}{c}(19) \\
38\end{array}$ & $\begin{array}{l}\text { (4) } \\
12\end{array}$ & $\begin{array}{c}(5) \\
5\end{array}$ & 1.9 & Not available \\
\hline Pencil & $\begin{array}{l}\text { (3) } \\
12\end{array}$ & $\begin{array}{l}(5) \\
10\end{array}$ & $\begin{array}{c}(20) \\
60\end{array}$ & $\begin{array}{c}(0) \\
0\end{array}$ & 2.9 & Available \\
\hline Rubber & $\begin{array}{l}(3) \\
12 \\
\end{array}$ & $\begin{array}{c}(13) \\
26 \\
\end{array}$ & $\begin{array}{c}(10) \\
30 \\
\end{array}$ & $\begin{array}{c}(2) \\
2 \\
\end{array}$ & 2.5 & Available \\
\hline
\end{tabular}

Findings in table 4.1.1.1 above, showed that teachers' ratings on the level of availability of geometrical instruments was generally low. Out of 11 items that were listed for study, 6 were reported available in these schools while 5 were not available. The presence of the items rated available was still not sufficient enough compared the number of users.

\subsubsection{Views of Head teachers}

An interview guide for Head teachers was administered. Five head teachers responded. None of them indicated that they had enough chalk-board instruments for their teachers nor for the learner's instruments. They attributed this to erratic funding by central government towards teaching and learning materials, particularly in the recent past.

\subsubsection{Researcher's Findings}

The researcher collected data on the presence of geometrical instruments in the selected five secondary schools in Masaiti district for both teachers and pupils. Table 4.1.3.1 show the results:

Table 4.1.3.1: Presence of Geometrical Instruments in selected Secondary Schools

Secondary schools

\begin{tabular}{|c|c|c|c|c|c|c|c|c|c|c|c|}
\hline \multirow[b]{2}{*}{$\begin{array}{l}\text { Geometrical } \\
\text { Instrument }\end{array}$} & \multicolumn{2}{|c|}{ Masaiti } & \multicolumn{2}{|c|}{ Chiwala } & \multicolumn{2}{|c|}{ Mushili } & \multicolumn{2}{|c|}{ Fiwale } & \multicolumn{2}{|c|}{ Kafulafuta } & \multirow[b]{2}{*}{$\%$} \\
\hline & $\begin{array}{l}\text { NO. } \\
\text { Avai } \\
\text { lable }\end{array}$ & $\begin{array}{l}\text { NO. } \\
\text { Not } \\
\text { Avai }\end{array}$ & $\begin{array}{l}\text { NO. } \\
\text { Avai } \\
\text { lable }\end{array}$ & $\begin{array}{l}\text { NO. } \\
\text { Not } \\
\text { Avai }\end{array}$ & $\begin{array}{l}\text { NO. } \\
\text { Avai } \\
\text { lable }\end{array}$ & $\begin{array}{l}\text { NO. } \\
\text { Not } \\
\text { Avai }\end{array}$ & $\begin{array}{l}\text { NO. } \\
\text { Avai } \\
\text { lable }\end{array}$ & $\begin{array}{l}\text { NO. } \\
\text { Not } \\
\text { Avai }\end{array}$ & $\begin{array}{l}\text { NO. } \\
\text { Avai } \\
\text { lable }\end{array}$ & $\begin{array}{l}\text { NO. } \\
\text { Not } \\
\text { Avai }\end{array}$ & \\
\hline $\begin{array}{l}\text { Chalk board } \\
\text { Compasses }\end{array}$ & 2 & 6 & 3 & 4 & 2 & 3 & 1 & 3 & 1 & 3 & 32 \\
\hline $\begin{array}{l}\text { Chalk board } \\
\text { Protractor }\end{array}$ & 1 & 7 & 2 & 5 & 0 & 5 & 1 & 3 & 1 & 3 & 18 \\
\hline $\begin{array}{l}\text { Chalk board } \\
\text { Ruler }\end{array}$ & 3 & 5 & 4 & 3 & 2 & 3 & 2 & 2 & 3 & 1 & 50 \\
\hline $\begin{array}{l}\text { Chalk board } \\
\text { Set Square }\end{array}$ & 1 & 7 & 2 & 5 & 0 & 5 & 1 & 3 & 0 & 4 & 14 \\
\hline Duster & 5 & 3 & 5 & 2 & 3 & 2 & 3 & 1 & 2 & 2 & 64 \\
\hline $\begin{array}{l}\text { Pupil's } \\
\text { Compasses }\end{array}$ & 15 & 64 & 41 & 18 & 6 & 35 & 5 & 43 & 4 & 25 & 28 \\
\hline $\begin{array}{l}\text { Pupil's } \\
\text { Protractor }\end{array}$ & 6 & 73 & 38 & 21 & 3 & 38 & 3 & 45 & 1 & 28 & 20 \\
\hline
\end{tabular}




\begin{tabular}{|c|c|c|c|c|c|c|c|c|c|c|c|}
\hline \multirow[b]{2}{*}{$\begin{array}{l}\text { Geometrical } \\
\text { Instrument }\end{array}$} & \multicolumn{2}{|c|}{ Masaiti } & \multicolumn{2}{|c|}{ Chiwala } & \multicolumn{2}{|c|}{ Mushili } & \multicolumn{2}{|c|}{ Fiwale } & \multicolumn{2}{|c|}{ Kafulafuta } & \multirow[b]{2}{*}{$\%$} \\
\hline & $\begin{array}{l}\text { NO. } \\
\text { Avai } \\
\text { lable }\end{array}$ & $\begin{array}{l}\text { NO. } \\
\text { Not } \\
\text { Avai }\end{array}$ & $\begin{array}{l}\text { NO. } \\
\text { Avai } \\
\text { lable }\end{array}$ & $\begin{array}{l}\text { NO. } \\
\text { Not } \\
\text { Avai }\end{array}$ & $\begin{array}{l}\text { NO. } \\
\text { Avai } \\
\text { lable }\end{array}$ & $\begin{array}{l}\text { NO. } \\
\text { Not } \\
\text { Avai }\end{array}$ & $\begin{array}{l}\text { NO. } \\
\text { Avai } \\
\text { lable }\end{array}$ & $\begin{array}{l}\text { NO. } \\
\text { Not } \\
\text { Avai }\end{array}$ & $\begin{array}{l}\text { NO. } \\
\text { Avai } \\
\text { lable }\end{array}$ & $\begin{array}{l}\text { NO. } \\
\text { Not } \\
\text { Avai }\end{array}$ & \\
\hline $\begin{array}{l}\text { Pupil's } \\
\text { Ruler }\end{array}$ & 33 & 46 & 47 & 12 & 17 & 24 & 21 & 27 & 8 & 21 & 49 \\
\hline $\begin{array}{l}\text { Pupil's } \\
\text { Set Square }\end{array}$ & 5 & 72 & 32 & 27 & 1 & 40 & 3 & 45 & 0 & 29 & 16 \\
\hline Pencil & 42 & 37 & 48 & 11 & 10 & 31 & 12 & 36 & 21 & 8 & 52 \\
\hline Rubber & 31 & 48 & 35 & 24 & 15 & 26 & 28 & 20 & 15 & 14 & 48 \\
\hline
\end{tabular}

Findings in table 4.1.3.1 above, showed that the number of geometrical instruments for both teachers and pupils were not sufficient. Out of 11 items that were listed for study, only the chalkboard ruler, duster and pencil reached $50 \%, 64 \%$ and $52 \%$ respectively. The other items recorded less than $50 \%$ availability. Therefore, apart from the duster, the other instruments were not adequate enough to be used efficiently and effectively in the study of geometry.

\subsection{EXTENT TO WHICH GEOMETRICAL INSTRUMENTS ARE USED.}

\subsubsection{Views of pupils}

Results of the learners' ratings on the use of these instruments are presented in Table 4.2.1.1 below.

Table 4.2.1.1: Learners' ratings on the extent of use of Geometrical Instruments in Secondary Schools.

\begin{tabular}{|c|c|c|c|c|c|c|}
\hline $\begin{array}{l}\text { Geometrical } \\
\text { Instrument }\end{array}$ & $\begin{array}{c}\text { Highly } \\
\text { Used } \\
\text { (4) }\end{array}$ & $\begin{array}{c}\text { Used } \\
\text { (3) }\end{array}$ & $\begin{array}{c}\text { Scarcely } \\
\text { Used } \\
(2)\end{array}$ & $\begin{array}{c}\text { Completely } \\
\text { Not Used } \\
\text { (1) }\end{array}$ & $\begin{array}{l}\text { Item } \\
\text { Mean }\end{array}$ & Comment \\
\hline $\begin{array}{l}\text { Chalk board } \\
\text { Compasses }\end{array}$ & $\begin{array}{c}(10) \\
40\end{array}$ & $\begin{array}{l}(36) \\
108\end{array}$ & $\begin{array}{c}(108) \\
216\end{array}$ & $\begin{array}{c}(102) \\
102\end{array}$ & 1.8 & Not used \\
\hline $\begin{array}{l}\text { Chalk board } \\
\text { Protractor }\end{array}$ & $\begin{array}{l}(5) \\
20\end{array}$ & $\begin{array}{c}(20) \\
60\end{array}$ & $\begin{array}{c}(115) \\
230\end{array}$ & $\begin{array}{c}(116) \\
116\end{array}$ & 1.7 & Not used \\
\hline $\begin{array}{l}\text { Chalk board } \\
\text { Ruler }\end{array}$ & $\begin{array}{l}(46) \\
184\end{array}$ & $\begin{array}{l}(75) \\
225\end{array}$ & $\begin{array}{l}(90) \\
180\end{array}$ & $\begin{array}{c}(45) \\
45\end{array}$ & 2.5 & Used \\
\hline $\begin{array}{l}\text { Chalk board } \\
\text { Set Square }\end{array}$ & $\begin{array}{c}(16) \\
64\end{array}$ & $\begin{array}{c}(25) \\
75\end{array}$ & $\begin{array}{l}(85) \\
170\end{array}$ & $\begin{array}{c}(130) \\
130\end{array}$ & 1.7 & Not used \\
\hline Duster & $\begin{array}{c}(190) \\
760\end{array}$ & $\begin{array}{l}(38) \\
114\end{array}$ & $\begin{array}{c}(16) \\
32\end{array}$ & $\begin{array}{c}(12) \\
12\end{array}$ & 3.6 & Used \\
\hline $\begin{array}{l}\text { Pupil's } \\
\text { Compasses }\end{array}$ & $\begin{array}{l}(9) \\
36\end{array}$ & $\begin{array}{l}(66) \\
198\end{array}$ & $\begin{array}{c}(110) \\
220\end{array}$ & $\begin{array}{c}(71) \\
71\end{array}$ & 2.1 & Not used \\
\hline $\begin{array}{l}\text { Pupil's } \\
\text { Protractor }\end{array}$ & $\begin{array}{l}(5) \\
20\end{array}$ & $\begin{array}{l}(53) \\
159\end{array}$ & $\begin{array}{c}(130) \\
260\end{array}$ & $\begin{array}{c}68) \\
68\end{array}$ & 2.0 & Not used \\
\hline $\begin{array}{l}\text { Pupil's } \\
\text { Ruler }\end{array}$ & $\begin{array}{c}(137) \\
548\end{array}$ & $\begin{array}{l}(68) \\
204\end{array}$ & $\begin{array}{c}(32) \\
64\end{array}$ & $\begin{array}{c}(19) \\
19\end{array}$ & 3.3 & Used \\
\hline $\begin{array}{l}\text { Pupil's } \\
\text { Set Square }\end{array}$ & $\begin{array}{l}(9) \\
36\end{array}$ & $\begin{array}{l}(53) \\
159\end{array}$ & $\begin{array}{l}(105) \\
210\end{array}$ & $\begin{array}{c}(89) \\
89\end{array}$ & 1.9 & Not used \\
\hline Pencil & $\begin{array}{c}(158) \\
632\end{array}$ & $\begin{array}{l}(64) \\
192\end{array}$ & $\begin{array}{c}(25) \\
50\end{array}$ & $\begin{array}{c}\text { (9) } \\
9\end{array}$ & 3.4 & Used \\
\hline Rubber & $\begin{array}{c}(130) \\
520\end{array}$ & $\begin{array}{l}(71) \\
213\end{array}$ & $\begin{array}{c}(34) \\
68\end{array}$ & $\begin{array}{c}(21) \\
21\end{array}$ & 3.2 & Used \\
\hline
\end{tabular}

Ratings by the learners on the extent to which the geometrical instruments are used in secondary schools in Masaiti district, showed that most of the important tools were not used. Out of 11 items that were listed for study, 6 were reported not used by both teachers and learners. 5 items were reported to be used.

\subsubsection{Views of Head teachers}

Five Head teachers from the selected schools were involved. The results were summarized in table 4.2.2.1 below.

Table 4.2.2.1: Head teachers' ratings on the extent to which Geometrical Instruments are used in Secondary Schools.

\begin{tabular}{|l|l|l|l|l|}
\cline { 2 - 5 } \multicolumn{1}{c|}{} & Highly Used & Used & Scarcely Used & Completely Not Used \\
\hline Teachers & $0(0 \%)$ & $0(0 \%)$ & $5(100 \%)$ & $0(0 \%)$ \\
\hline Pupils & $0(0 \%)$ & $0(0 \%)$ & $5(100 \%)$ & $0(0 \%)$ \\
\hline
\end{tabular}

Findings in table 4.2.2.1 show that Head teachers unanimously indicated that geometrical instruments for both teachers and pupils were rarely used. 


\subsection{CHALLENGES FACED BY LEARNERS}

4.3.1 Views of learners

Table 4.4.1.1: Shows rated challenges faced by learners when using geometrical instruments -submitted by learners $(\mathbf{n}=\mathbf{2 5 6})$

\begin{tabular}{|c|c|c|}
\hline Challenges & Frequency & Percentage \\
\hline Lack of geometrical instruments & 158 & 61.7 \\
\hline Difficulty geometry language & 83 & 32.4 \\
\hline Lack of practice & 147 & 57.4 \\
\hline Lack of interest & 46 & 18.0 \\
\hline Sharing geometrical instruments & 27 & 10.5 \\
\hline Time consuming & 18 & 7.0 \\
\hline Lack of knowledge on the use of instruments & 34 & 13.3 \\
\hline Inability to measure & 23 & 9.0 \\
\hline Bad attitude by teachers & 91 & 35.5 \\
\hline
\end{tabular}

As shown in table 4.3.1.1 above, $61.7 \%$ of the respondents indicated lack of geometrical instruments which was a biggest challenge. $35.5 \%$ of the responses referred to bad attitude by teachers.

\subsubsection{Views of teachers}

Reports by teachers were similar to the ones which the learners submitted. They acknowledged that learners found it very difficult to attempt questions which required the use of geometrical instruments. All the 28 teachers that were engaged attributed this to inadequate geometrical instruments, inability to comprehend geometrical language, difficulties in handling instruments like the pair of compasses and the protractor, stiff finger muscles, shaking, and in some cases poor sight by their pupils. Because of these challenges, teachers added that learners' interest in geometry drastically declined. Furthermore, teachers reported that pupils' work in geometry was always not very clear because construction of angles, lines, and shapes were done in ruled exercise books. The lines of the exercise books made the work look congested, consequently inhibiting understanding of concepts by the learners.

\subsubsection{Views of Head teachers}

Out of five Head teachers that were consulted only two $(40 \%)$ responded to the question. Their responses concurred with the findings by Onche (2014), who pointed out that, lack of using instructional materials in secondary schools was very much related to insufficient skills and creativity among teachers and learners.

\subsubsection{Researcher's observations}

The researcher purposively chose two classes from Masaiti Boarding School; grade 11C and grade 11D as typical class and ideal class respectively in order to establish the challenges that learners faced when answering questions which required the use of geometrical instruments. Lessons containing such activities were organized in form of Activity 1 and Activity 2.

Ideally, the researcher was interested in observing the participation of learners in the activities. Firstly, a pre-test of 40 minutes duration was administered to the two groups at the same time. As the test was going on, the learners were seen to be restless. They moved up and down to look for some instruments which they shared. In the process, as a result of this situation, even noise was produced which the subject teacher failed to stop completely. The noise was as result of mini consultations about some concepts in the test and asking for mathematical instruments from those who had. Some pupils who were stuck were seen sleeping due to loss of concentration. The researcher discovered that majority of the learners lacked pre-requisite knowledge which was another major challenge. It did not reflect well to hear from some pupils that they did not know names of some instruments like a set square and a protractor. Some did not know properties of basic shapes like a rectangle and a square. So when they were asked to draw such shapes, they could hardly attempt. This challenge compelled one pupil in the ideal class, despite being provided with a fully equipped mathematical set, decided to draw a circle using a protractor.

\subsection{THE EXTENT TO WHICH USE OF GEOMETRICAL INSTRUMENTS AFFECT LEARNER'S PERFORMANCE.}

There was a pre-test for both groups; the typical class and the ideal class. The pre-test was given to the two groups at the same time. Similar questions to the pre-test were used for the post-test. The conditions for both tests were the same to the two groups. The teacher marked both tests out of $100 \%$. Pre-test and post-test results were record as shown in tables 4.4.1 and 4.4.2 below respectively. 
Table 4.4.1: Pre-test results for the typical and ideal classes $(n=80)$

\begin{tabular}{|l|c|c|c|c|}
\hline & \multicolumn{2}{|c|}{ TYPICAL CLASS } & \multicolumn{2}{c|}{ IDEAL CLASS } \\
\hline Marks & Frequency & Percentage & Frequency & Percentage \\
\hline $90-100$ & 0 & 0.0 & 0 & 0.0 \\
\hline $80-89$ & 0 & 0.0 & 0 & 0.0 \\
\hline $70-79$ & 0 & 0.0 & 0 & 0.0 \\
\hline $60-69$ & 0 & 0.0 & 0 & 0.0 \\
\hline $50-59$ & 0 & 0.0 & 0 & 0.0 \\
\hline $40-49$ & 2 & 5.0 & 1 & 2.5 \\
\hline $30-39$ & 4 & 10.0 & 3 & 50.0 \\
\hline $20-29$ & 18 & 45.0 & 20 & 25.0 \\
\hline $10-19$ & 11 & 27.5 & 10 & 15.0 \\
\hline $0-9$ & 5 & 12.5 & 6 & $\mathbf{1 0 0}$ \\
\hline Total & $\mathbf{4 0}$ & $\mathbf{1 0 0}$ & $\mathbf{4 0}$ & \\
\hline
\end{tabular}

Table 4.4.1 presents pre-test scores for the typical and the ideal classes. The results indicated that none of the pupils from both groups scored above 50\%. All the pupils performed below average.

Table 4.4.2: Post-test results for the control and experimental groups $(n=40)$

\begin{tabular}{|l|c|c|c|c|}
\cline { 2 - 5 } \multicolumn{1}{c|}{} & \multicolumn{2}{c|}{ TYPICAL CLASS } & \multicolumn{2}{c|}{ IDEAL CLASS } \\
\hline Marks & Frequency & Percentage & Frequency & Percentage \\
\hline $90-100$ & 0 & 0.0 & 1 & 0.0 \\
\hline $80-89$ & 0 & 0.0 & 2 & 5.5 \\
\hline $70-79$ & 0 & 0.0 & 5 & 12.5 \\
\hline $60-69$ & 2 & 5.0 & 9 & 22.5 \\
\hline $50-59$ & 2 & 5.0 & 6 & 15.0 \\
\hline $40-49$ & 5 & 12.5 & 6 & 15.0 \\
\hline $30-39$ & 8 & 20.0 & 8 & 20.0 \\
\hline $20-29$ & 10 & 25.0 & 3 & 7.5 \\
\hline $10-19$ & 11 & 27.5 & 0 & 0.0 \\
\hline $0-9$ & 2 & 5.0 & $\mathbf{4 0}$ & $\mathbf{1 0 0}$ \\
\hline Total & $\mathbf{4 0}$ & $\mathbf{1 0 0}$ & 0 \\
\hline
\end{tabular}

Table 4.4.2 presents post-test scores for the typical and the ideal classes. The results indicated that none of the pupils from both groups scored above $90 \%$. Only 4 (10\%) scored above 50\% from the typical class while 17 (42.5\%) from the ideal class scored above $50 \%$. Additionally, table 4.4 .3 show a summary of some descriptive statistics analysed on SPSS.

Table 4.4.3: Presents Descriptive Statistics

\begin{tabular}{|c|c|c|c|c|c|c|}
\hline & $\mathrm{N}$ & Mean & Std. Deviation & Variance & \multicolumn{2}{|c|}{ Skewness } \\
\cline { 2 - 7 } & Statistic & Statistic & Statistic & Statistic & Statistic & Std. Error \\
\hline Typical class posttest & 40 & 28.93 & 14.826 & 219.815 & .940 & .374 \\
Ideal class posttest & 40 & 43.20 & 18.108 & 327.908 & .234 & .374 \\
Typical class pretest & 40 & 19.75 & 9.347 & 87.372 & .033 & .374 \\
Ideal class pretest & 40 & 19.80 & 9.560 & 91.395 & .262 & .374 \\
Valid N (list wise) & 40 & & & & & \\
\hline
\end{tabular}

Pre-test results showed that the two groups were of equal strength before the intervention. The typical class had mean statistic 19.75 and standard deviation 9.35 while the ideal class had mean statistic 19.80 and standard deviation 9.56. However, the post-test results showed improvement in performance in the ideal class as compared to the typical class.

\subsection{HYPOTHESIS FOR THE GENERAL OBJECTIVE}

The researcher made the following hypothesis:

$\boldsymbol{H}_{1}$ : There is a significant difference in mathematical performance between learners who learn with sufficient geometrical instruments and those who learn with insufficient geometrical instruments.

$\boldsymbol{H}_{0}$ : There is no significant difference in mathematical performance between learners who learn with sufficient geometrical instruments and those who learn with insufficient geometrical instruments.

The results of the independent t-test for the statistical difference between the means of the learners from the group with sufficient geometrical instruments and those from the group with insufficient geometrical instruments were calculated using Excel software. Table 4.5.1 presents these results. 
Table 4.5.1: Independent t- test analysis of significance between the means of the two groups. t-Test: Paired Two Sample for Means

\begin{tabular}{lrc}
\hline & TYPICALPOSTTEST & IDEAL CLASS POST TEST \\
\hline Mean & 28.925 & 43.2 \\
Variance & 219.8147436 & 327.9076923 \\
& & \\
Observations & 40 & 40 \\
Pearson Correlation & 0.544824186 & \\
Hypothesized Mean Difference & 0 & \\
Df & 39 & \\
t Stat & -5.651760865 & \\
P $(T<=$ t) one-tail & $7.88556 \mathrm{E}-07$ & \\
t Critical one-tail & 1.684875122 & \\
P $(T<=t)$ two-tail & $1.57711 \mathrm{E}-06$ & \\
t Critical two-tail & 2.02269092 & \\
\hline
\end{tabular}

From table 4.5.1, there was a significant difference in performance between the learners from the group with sufficient geometrical instruments (ideal class) and those from the group with insufficient geometrical instruments (typical class). This interpretation was based on the fact that the $\mathrm{p}(\mathrm{T}<=\mathrm{t})$ two-tail $=1.58$ was less than the critical t-value of 2.02, at 0.95 level of significance. Therefore the null hypothesis was rejected and concluded that there was a significant difference in mathematical performance between learners who learn with sufficient geometrical instruments and those who learn with insufficient geometrical instruments.

\subsection{CONCLUTION AND RECOMMENDATIONS}

The main objective of this study was to establish the challenges which are faced by learners when answering questions that require the use of geometrical instruments in Masaiti district and how these affect their performance. This was due to the fact that majority of pupils in Masaiti were seen to shun questions that required the use of geometrical instruments both in mock and final examinations. Of course utilisation of any instructional materials largely depends on their availability. The extent to which use of geometrical instruments affect learner's performance was determined and was found to be highly rewarding in the study of geometry

\subsection{CONCLUTIONS}

From the study findings it is apparent that many schools in the study area did not have sufficient geometrical instruments. Consequently, teachers and learners rarely used them. Although all the teachers under study agreed that use of geometrical instruments was important in contributing to learners' academic performance, they did not show much concern to have these instruments available in their classrooms. Equally, Head teachers seemed to have a short sight on this matter. Normally, heads of schools are supposed to be instructional supervisors, to ensure that learners were provided with quality education through quality instructional resources. Lack of understanding of the underlying principle in the use of geometrical instruments in schools, Head teachers and teachers may be the reason for the situation found by this study. Learners traced the causes of difficulty in learning of concepts in geometry due to non-availability of instruments, poor teachers' methodology, and lack of practice, insufficient time allocation, and incomprehensible geometry language. The following challenges were found; sharing instruments, inaccurate measurements, lack of interest and pre-requisite knowledge, use of free hand, difficulty geometry language, time consuming, use of inappropriate instruments and defective instruments, stiff finger muscles, shaking hands and poor sight. The hypothesis was tested with the independent t-test on Excel software. The results showed that learners who used sufficient instruments performed better than those who shared. This was because the $\mathrm{p}(\mathrm{T}<=\mathrm{t})$ two-tail $=1.58$ was less than the critical $\mathrm{t}$-value of 2.02 , at 0.95 level of significance. It was concluded that practice with instruments can improve performance in geometry.

After the intervention, the learners in the ideal class appreciated the use of geometrical instruments in the study of geometry. This saw a significant improvement in terms of performance by pupils in this class as compared to the typical class. A good number of learners from the ideal class demonstrated good skills in the use of geometrical instruments in the study of geometry as compared to those from the typical class. They showed much more sense in terms of handling the geometrical instruments during the lessons. About $50 \%$ of them purposefully used the pair of compasses, protractor and set squares as compared to their colleagues from the other class. The hypothesis was tested with the independent t-test on Excel software. The results showed that learners who used sufficient instruments performed better than those who shared. This was because the $\mathrm{p}(\mathrm{T}<=\mathrm{t})$ two-tail $=1.58$ was less than the critical t-value of 2.02 , at 0.95 level of significance. It was therefore, concluded that practice with instruments can improve performance in geometry.

The current situation in Masaiti district does not ultimately support the provision of quality education in the 
study of geometry. Stake holders need to collaborate in order to tackle this problem. School Head teachers ought to put up a deliberate policy of ensuring that their teachers have enough chalkboard instruments and that parents secure mathematical sets for their children. Without these instruments in place, the study of geometry by our learners will remain a paradox.

\subsection{RECOMMENDATIONS}

Based on these findings, the following recommendations are considered appropriate:

i. This study recommends that since learners taught geometry using geometrical instruments perform better than those who are taught using abstract methods, learners should be taught by use of geometrical instruments for better performance in geometry in particular, and mathematics in general.

ii. Government through the ministry of education should consider to provide geometrical instruments for both teachers and pupils in various schools for teaching of concepts in geometry.

iii. School authorities should allocate sufficient time for teaching and learning of geometry since this branch of mathematics if practical it requires hands on. With more practice, learners will be skillful, subsequently develop spatial sense.

iv. Teacher trainers (Colleges and Universities) to equip the teacher trainees with appropriate skills useful in the preparation of instructional materials like geometrical instruments.

v. Since knowledge gaining is a continuous process, workshops on the use of and updates of geometrical instruments should be organized on regular basis for teachers and school managers.

vi. Curriculum planners should endeavor to arrange the geometry concepts in a way comprehensible to the learners and not be too complex for teachers to teach.

\section{ACKNOWLEDGEMENT}

I thank God for my supervisor Mr. Jacob Hamanenga for his technical and professional input during the entire period of my research project. He tirelessly continued to correct my work and offered pieces of advice whenever I went to him. I am grateful to the entire team of the Copperbelt University for their valuable academic and professional guidance.

My gratitude also goes to the targeted secondary school teachers of mathematics and the grade 11 pupils in Masaiti district who responded to the questionnaire items. Thanks to the head teachers who not only allowed me to conduct research in their schools but also completed the interview guide. Thanks to the District Education Board Secretary for Masaiti district Mrs. Elizabeth Mwila Ng'onga for the permission which she granted me to get the required information from secondary schools in her district. I sincerely extend my gratitude to my head teacher Mr. Richwell Ndlovu who never got tired of giving me permissions to leave the school in pursuance of this degree. I would also express my appreciation to my cousin Mr. Chola Kopeka for countless technical support, and my friends Joseph Ntaya and Setwin Mufalo who skilfully edited my work.

God bless you all.

\section{REFERENCES}

1. Adegun, I.K. \& Adegun, B.O. (2001). Students and teachers' views of difficult areas in mathematics syllabus: Basic requirement for science and engineering education. Journal of Education and Practice, 4(12), 2013, 235-243.

2. Adolphus, T. (2011). Problems of teaching and learning of geometry in secondary schools in rivers state, Nigeria. International Journal of Emerging Sciences 1(2): 143-152.

3. Babayomi, A. A. (1999). Comparative study of the Teaching and Learning Resources in Private and Public Secondary Schools in Logos State. Master's Thesis, Department of Educational Administration, University of Lagos, Nigeria.

4. Bassey, S. W., Ndiyo, N.A. \& Joshua, M.T. (2010). The Influence of Instructional Materials on Mathematics Achievement of Senior Secondary Students in Akamkpa Local Government Area of Cross River State, Nigeria. African Journal of Educational Studies in Mathematics and Sciences Vol. 8, 2010.

5. Battista, M. T. (1999). The Mathematical Miseducation of America's Youth: Ignoring Research and Scientific Study in Education. Phi Delta Kappan 80(6)425-433.

6. Chikwere, P. \& Ayama, K. (2016).Teaching of Geometric Construction in Junior High School: An Intervention. Journal of Elementary Education Vol.26, No. 139-146.

7. Eniayeju, P. A. (1987). A diagnosis of the O-level science students' performance: the Kano State Case study. Nigeria Educational forum 10(2), $301-208$.

8. Examinations Council of Zambia, ECZ, (2014). Examinations Performance Report. Lusaka, Zambia.

9. Examinations Council of Zambia, ECZ, (2015). Examinations Performance Report. Lusaka, Zambia.

10. Examinations Council of Zambia, ECZ, (2016). Examinations Performance Report. Lusaka, Zambia. 
11. Examinations Council of Zambia, ECZ, (2017). Examinations Performance Report. Lusaka, Zambia.

12. Fabiyi, T.R. (2017). Geometry Concepts in Mathematics Perceived Difficult to Learn by Senior Secondary School Students in Ekiti State, Nigeria. Journal of Research \& Method in Education (10SR-JRME) Vol. 7.

13. Geddes, D. \& Fortunato, I. (1993). Geometry: Research and Classroom Activities, in D.T. Owens, Ed., Research Ideas for the Classroom: Middle Grades Mathematics, New York: Macmillan.

14. Kombo, D.K and Tromp, D.L.A. (2011). Proposal and Thesis Writing: An Introduction. Nairobi: Pauline Publishers Africa.

15. Madanzi, M. (2015). Challenges Faced by Learners in Geometrical Constructions and Locus: http;//hdl.handle.net/11196/1477.

16. Ministry of Education, Science, Vocational Training and Early Education. (2013). Mathematics Syllabus (Grades 8 and 9). Curriculum Development Centre, Lusaka.

17. Mugenda, O. M. \& Mugenda, A. G. (2003). Research methods. Nairobi: African Centre for Technology Studies (ACT).

18. Mwiria, K. (1995). Issues in Educational Research in Africa. Nairobi: East African Educational Publishing Limited.

19. Okon, A. E. P. (2005). Effects of inadequacy of instructional materials in the teaching of social studies in junior secondary schools in Abak LGA of Akwa Ibom State, Nigeria. An unpublished B.Ed. Project of University of Calabar.

20. Onche, A. (2014). Meeting the Challenge of Accessibility and Utilization of Modern Instructional Materials in Rural Secondary Schools in Nigeria. International Journal of Multidisciplinary Studies. I, (2): 1 - 13.

21. Paulina, M.M. (2007). Perspectives on the Teaching of Geometry for the $21^{\text {st }}$ century (Dordretcht: Kluwer, 2007

22. Sarfo, S.K., Eshun, G., Elen, J., \& Adentwi, K. I. (2014). Towards the solution of abysmal performance in mathematics in Junior High Schools: comparing the pedagogical potential of two designed interventions. Electronic Journal of Research in Educational Psychology 12(3): 763-784

23. Tety, J. L. (2016). Role of Instructional Materials in Academic Performance in Community Secondary Schools in Rombo District. East African Education Publishing Limited. 